\title{
TOWARDS A SPATIAL CRITIQUE OF IDEOLOGY: ARCHITECTURE AS A TEST
}

\author{
Karol Kurnicki \\ Institute of Sociology, Jagiellonian University, Grodzka 52, 31-044 Kraków, Poland \\ E-mail:karol.kurnicki@uj.edu.pl
}

Received 21 November 2013; accepted 10 February 2014

\begin{abstract}
The article presents the outline for the theory of ideological space. The ideological properties of space are reconsidered by the juxtaposition of Lefebvre's and Bourdieu's theories. The resultant reconciliation points towards the notion of spatial critique of ideology as well as the possibility of employing ideology for critique of space. The notion of a test (as characterized by Boltanski) is introduced to show the importance of capabilities of actors and objects in the process of critique. The article emphasizes the exceptional significance of architecture for the construction of critical positions. The architecture is described as a form of a test. In so doing, the architecture is characterized as one of the essential elements of possible social emancipation. In effect, both the social responsibilities of the architecture and its critical role are underscored.
\end{abstract}

Keywords: ideology, space, architecture, critique, test.

Reference to this paper should be made as follows: Kurnicki, K. 2014. Towards a spatial critique of ideology: architecture as a test, Journal of Architecture and Urbanism 38(1): 80-89.

\section{Introduction}

Henri Lefebvre postulates a science of the city which could become a cornerstone of urban life in his work "Theses on the City, the Urban and Planning" (2000). However, as he observes, understanding of a city is insufficient because "a social and political force capable of putting these means into oeuvres is equally indispensable" (Lefebvre 2000:178). This thesis is a call for the emergence of a power institution which would allow for the planning of urban society and, at the same time, an emphasis of the necessity to construct a physical space that would be in accordance with social needs. In this article I shall attempt to analyze the possibility of using ideology as a starting point for the creation of a political force in space by means of architecture.

The ideological properties of space have now been naturalized in urban studies and are currently treated as being somewhat obvious. Various attempts to explain and overcome the issue of ideology with regards to space and architecture (see for instance: Castells 1977; Tafuri 1998) prove insufficient. Most of these approaches suffer from inadequate positioning of ideology with regard to architecture, which either strengthens the opposition between them or considers ideology in strictly political terms (Cuthbert 2006) and concentrates on material production of totalitarian and authoritarian states. For precisely this reason it is required to revisit the problem in order to firstly, grasp it theoretically, and secondly, to show its critical potential. It is necessary to enunciate in what ways space is simultaneously a product and a producer mediating social relations (Goonewardena 2004: 168). Although a relational approach to society, ideology and space may seem like a postmodern gimmick (relational, so maybe relative!); at the same time it is one of the few ways of comprehending and offering criticism of contemporary cities and urbanization. As a social construct each of these things has a very concrete and material facet. In the first section of the article, I shall attempt to show how space is both ideological and political. In a more radical way, the issue is space as materialized 
ideology. To describe that issue it is possible to draw on the traditional Marxist theory of ideology, especially as per Althusser (1994). However, this tradition does not provide us with fully satisfactory answers, mainly because of its underpinning of the strict separation of reality and illusion (science and ideology).

The critique of existing relations and the emergence of new social and spatial models are virtually inevitable. It is therefore necessary to investigate ideological socio-spatial relations in order to establish critical positions which would be able to contend with the dominating powers of today. For many reasons the position of external critique is no longer tenable, if ever it was. It is not to say, however, that the domination is all-encompassing and critique impossible. The problem is rather with the invention and employment of ideologies, values, norms and resources which would be strong enough to break with existing relations of dominations. Contrary to unifying approaches to space and society, such as globalization or world cities discourses, possibilities of critique exist in the internally and horizontally divided social structure, which allows for shifting from one position to another. Spatial dimension is of crucial importance because it binds traditionally understood ideological struggles with the concrete and material characteristics of people and objects.

The second and third sections of the article will try to explain the key position of architecture and buildings in the context of social and spatial critique. Of particular help will be the analytical framework proposed by sociologists from the so-called French pragmatic school, especially the works of Luc Boltanski. I shall not be attempting to simply apply this framework to the analysis of space, but rather to show that certain elements of this "sociology of critique" (as it is sometimes called in contrast to critical sociology) may prove useful for the analysis of the social production of space. In the case of architecture, the key element is a category of test. The general question is about the specific conditions and strength of arguments which would allow being critical in the first place, given that "everything is ideological". And why is space and architecture of such importance for the creation of a strong social critique?

\section{Ideologies and space}

It is somewhat customary in urban studies to recall Henri Lefebvre's work while analyzing spatial relations (Kipfer et al. 2008: 1-23). It is not the case with Pierre Bourdieu. With very few exceptions (e. g. Harvey 1987; Savage 2011) his sociological work has not been used by urban theorists and researchers. Indeed, he seems to have been preoccupied with the questions regarding time and its different social usages. However, spatial issues have also been very important to him, to the extent that his "The Social Structures of Economy" (2005) is essentially a socio-spatial analysis. Similarly, the importance of space to Bourdieu is evident in "The Weight of the World" (1999) where meticulous, almost ethnographic descriptions of neighbourhoods, houses or interiors are at least as meaningful as interviews for the analytic description of social problems. I will try to show that Bourdieu's social theory may also be helpful with regard to the investigation of the ideologies of space, not only because of his preference for spatial terms (such as field, position, game or social space). Juxtaposition of Lefebvre and Bourdieu may seem unorthodox inasmuch as their theoretical work was distinct and their role in the political and intellectual life of France dissimilar, despite the fact that the latter became increasingly engaged in political matters, assuming to some extent the position of the "public intellectual" vacant after the death of Foucault (see: Swartz 2005). The former is widely known to have been active in French political life from as early as the 1940s (Stanek 2011).

Lefebvre does not go beyond a typical definition of ideology as a discourse even though he attempts to situate it in the context of social practices (2010:44). On the other hand, Bourdieu is critical towards the notion of ideology in general, mainly because of its previous misuse and association with "false consciousness", and uses instead the term illusion or doxa. As stated by him, ideology as a term is compromised for it is unreasonably related to issues of consciousness and the possibility of gaining pure knowledge (Bourdieu, Eagleton 1994: 266). At the same time, the both abovementioned positions are encumbered with a typical mistake which has to do with an attempt to find a position external to ideological constraints. This kind of position is especially difficult to take and sustain in the context of the theory of space. It is so because, perhaps paradoxically, in space there are no external positions, at best we can talk about centre - periphery or in-between positions. Therefore the explanation of the issue of ideological space can be undertaken with the help of Lefebvre and Bourdieu on the condition that their theories are mutually reconsidered. In this article Bourdieu's work also is significant because it is representative of the critical sociology the shortcomings of which must be overcome in order to formulate a new critique of ideologies in space. At the same time it is one of the things shared by Bourdieu and Lefebvre. The former brilliantly showed how domination works in a society and how the social structure is permanently reproduced almost to the extent of being fixed. The latter is known to be more 
optimistic and still gives us hope that there are dialectical paths towards a spatial urban revolution (Lefebvre 2000: 147-159, 2003).

The most important theoretical innovation of Bourdieu, which can be found in "Outline of a Theory of Practice" (1995), is the surpassing overstepping of traditional opposition between the social structure (structuralism, functionalism, etc.) and the individual (phenomenology, symbolic interactionism, etc.) through an attempt to understand their mutual relations (see: Joas, Knöbl 2011). His aim was not to reconstruct strict division between scientific terms but rather to relationally connect different social strands in order to create a better understanding of society.

The problem with achieving this aim stems above all from the fact that sociology is a logical science. Thus it is almost impossible to describe social relations without blurring the definitions of terms which are involved in those relations. It is noticeable in one of Bourdieu's central theoretical achievements, habitus. Throughout his writings he struggles to provide a proper definition of habitus, which ranges from famous "structured structures predisposed to function as structuring structures" (Bourdieu 1990: 53) to comprehending it as the only durable ground for freedom in action (1999: 340). It is to some extent analogous to Lefebvre's spatial triad (2010). However, it is noticeable that by identifying spatial triad as a dialectical construct, to a large extent Lefebvre avoids the problems of definitions and at the same time maintains clearer boundaries between the three elements (see: Kipfer 2008: 29). However, for exactly this reason Lefebvre's positioning of ideology within spatial relations is limiting its critical capacities, even though it is directly related both to the material sphere and everyday life (2010: 90). Bourdieu's fuzzy definitions and situating habitus between what is given and what is active, as both embodied and material structure reproducing social relations, is what allows us to see ideology as also having different forms, including a spatial one.

It can be compared to Althusser's remark that "not spiritual but material existence of 'ideas' or other 'representations' is indeed necessary if we are to advance in our analysis of the nature of ideology" (1994: 125). $\mathrm{He}$ is even closer to Bourdieu's theory of practice in observing that "an ideology always exists in an apparatus, and its practice, or practices. This existence is material" (1994: 126). It brings us closer to the notion of ideological space, albeit the issue of relation between ideology and space still remains. Against the structuralist orientation of Althusser, it cannot be claimed that it is a one-way relationship in which dominating groups or classes impose their ideologies on the dominated and therefore ensure the reproduction of the mode of production. Moreover, his insistence on the division between ideology and science can hardly be supported (see: Eagleton 1991: 136-146). It is evident especially in a city and space in general, which is constantly transforming, persistently being practiced and recreated, sometimes against the interests of dominating groups.

Likewise, architecture can be considered a materialized ideology, but such that is not given once and forever. It is not so just because of the ageing of materials or going out of fashion. The reason is in the very nature of architecture as a material process, which has different functions depending on the context, users or historical circumstances and is to a large extent determined by complicated methods of construction. Hence, the investigation of resilience and reproduction of ideology should not concentrate on material construction itself, but rather on the functions which it supports in the context of production of practices and habituses in everyday life. Žižek (1994) notices something similar when he observes that ideology is not about "true" or "false" (i. e. about the logical relation to "how things are") but rather about its functionality within existing power relations.

Similarly, in space it is irrelevant whether a building epitomises power relations but rather to what extent it maintains existing relations of domination. Functions of ideological space consist in the fact that space determines a scope of possible social practices and therefore influences people's habituses in their very material aspect (Bourdieu, Eagleton 1994: 269). In the traditional theory of ideology of Marxist orientation a social change is associated with the possibility of gaining true knowledge of social relations which would help emancipation. However, in the context of material ideology, a social change is possible mainly through transformation of spatial arrangements which are capable of fixing or stabilizing habituses and enable domestication. In most cases it is not change we observe, but reproduction and stabilization of social relations in space. According to Bourdieu, "part of the inertia of the structures of social space results from the fact that they are inscribed in physical space and cannot be modified except by a work of transplantation, a moving of things and uprooting and deporting of people, which itself presupposes extremely difficult and costly social transformation" (Bourdieu et al. 1999: 124). I will try to argue that transformation is nevertheless possible without extraordinary means.

The issue of ideological space also implies actual transparency or naturalization of space. Very rarely is space considered truly ideological, and the space of everyday life particularly so. Following Bourdieu, it is possible to say that because of that it is even more ideological for it is part of unquestionable doxa, and "by using doxa we accept many things without knowing 
them, and that is what is called ideology" (Bourdieu, Eagleton 1994: 268). Therefore on the one hand there is a space, which although created by ideological processes, functions as reality and on the other the practical difficulty of questioning this reality. Gaining knowledge of spatial relations is not enough. When dealing with material space a person is engaged in real illusio, an ideological relation based on the impossibility of taking an external position, stepping aside and, in consequence gaining a potential for change. After all it is much easier to define theoretically one's own position in space than to practically surpass it by bodily transcendence or material transformation. At the same time, it is this materiality that enables change which is not only on the level of representation but also substantially differentiated. The critique of spatial relations depends thus not on knowledge of space but primarily on the interrelationship of practical everyday problems and material apparatuses. It chimes to some extent with Lefebvre's spatial triad, only here the issue is the relation between spaces of representation and spatial practices on the one hand and representations of space (including ideology) on the other.

Space and architecture can be considered ideological for another reason related to the issue of the naturalization of materiality. Space as a resource is finite. Construction of a building or a bigger project is ideological. It requires group level mobilization and involves many people and material as well as non-material things. More importantly, building means a choice from many potential solutions and materialization (realization) of only one of them. In that sense building is of a paradoxical and double nature, both positive (in creation of something new) and negative (in rejection of a variety of possibilities).

Architecture is ideological not only because it determines practices and shapes habituses, but also because it is in fact an answer to the question of those future determinations. It answers the question "what will be?" at least as strongly as to the question of "what is?" It also means that it articulates dominant political powers and configurations because not every group has equal footing to decide about architectural answers. Architects and urbanists cannot be considered a privileged group either. As Leach notices, "The very presence of architecture gives it a social impact, so that any 'negativity', any critical capacity within architecture, is all but cancelled by the 'positivity' of its presence. (...) The very physicality of architecture always threatens to install a new status quo, and undermines its capacity to be 'subversive"' (1999: 116). The same can be said of architecture the function of which is utilitarian and which is rarely viewed as aesthetic, such as warehouses, transportation systems and projects or social housing. The answers advocated by architectural and urban planning are not final, because, as Massey (2005: 10-11) points out, space is processual and entails the possibility of the existence of multiplicity and diversity. However, actual as well as perceived realization of this multiplicity is very difficult. To put it differently, despite the existence of complicated spatial relations and concurrent ideologies, what we observe is a rather constant reproduction of domination throughout history, technological innovation notwithstanding. It is again the same issue of functionality of ideology in space, which in Bourdieusian terms can be called material generative structure, simultaneously and "as if by magic" creating and created by society.

The abovementioned arguments can be considered as showing the factual impossibility of critique, especially such that would not fall back into existing ideological systems. Nevertheless, if we agree on the fact of ideological space, it is a strategic error to look for an external non-ideological position. In contrary, it is more productive and reasonable to use existing ideologies for the purpose of critique. If everything can be deemed ideological, the only way forward is to submit even more ideological propositions. Moreover, the characteristic of being ideological is quite complicated in itself, in spite of its apparent self-evidence. In practical (especially everyday) critique claiming everything ideological is too general and insufficient. As in the example of urban sociology and urban studies, ideology is often simultaneously exposed, overlooked and treated as natural, which actually enhances ideological functioning.

It is also necessary to point out the conditions in which emphasizing ideological space can be used as a critical tool. Externality of ideology exists only as much as it is still unrevealed, for instance in everyday practices. To return once again to Althusser and his notion of interpellation, it can be said that ideology can best be recognized not in space in general, but rather in its concrete functions, particularly in persons and objects. In other words, it is a task requiring movement on different levels. The existence of a building is not ideological in itself, but only within a wider ideological context and inscribed in a totality of relations: why is a building here and not elsewhere?, what purpose does it serve?, what is its influence and role?, does it create practices efficiently?, etc. It is even more crucial if we accept that, as Goonewardena posits, "space plays a mediating role between the social totality (our "real conditions of existence") and the representation of our relationship to that totality ("ideology")" (2004: 168). The major task of critique is the analytical identification of the mediating role of ideology. The tool of critique is a test. 


\section{Space and the testing of architecture}

The notion of a test, which will be reinterpreted and reappropriated in this article in order to analyze architecture and move towards its critique, is taken from so-called French pragmatic sociology. This strand of sociology is unequivocally disapproving of Pierre Bourdieu's critical sociology. However, there are authors who call attention to the possibility of combining his theory with this "sociology of critique" (see: Bénatouil 1999; Celikates 2006); although not without opposition from its proponents (Thévenot 2011; Blokker, Brighenti 2011). The notion of a test is one of the main categories of social analysis of conflicts in the context of values and justifications (Boltanski, Thévenot 2006). It is worth noting that the category was first used with a similar meaning by Bruno Latour, who emphasizes that it is related to a trial (even to a verb "to try") rather than a test (Latour 1993:153). This double signification of trial/test is important to remember with regard to the ideological role of architecture outlined in this text.

It is necessary to summarize shortly the model of practical justifications presented by Luc Boltanski and Laurent Thévenot in "On Justification", even though it was revised by the authors themselves in their later studies. Boltanski and Thevenot have indentified six main models of polity, also called political forms of worth: inspired, domestic, fame, civic, market and industrial. Their claims are evident in both classical works of political philosophy and contemporary handbooks for entrepreneurs and union representatives, which they used for their analysis. Those polities are at the same time bases for justifications in real-life situations of dispute and conflict. Social actors refer to one of the orders of worth in situations when their position is required to be explained or conflict needs to be resolved.

The basic social competence is the ability to generalize one's position, but also to shift between different kinds of justifications. For instance, sometimes it is necessary to present arguments related to someone's role as a citizen (and the social rules of citizenship) and then change to the arguments of a market nature (efficiency, etc.). What is important is that the sort of arguments and justifications referred to by the actors depends mainly on situational conditions. A situation is not a free-floating discourse; it is strongly grounded and limited. Objects are a very important aspect of a situation and are active in a dispute, they can distort sharpness or "cleanness" of justification or be activated to present it strongly: "with the help of objects, which we shall define by their belonging to a specific world, people can succeed in establishing states of worth.
A test of worth cannot be reduced to a theoretical debate. It engages persons, in their bodily existence, in a world of things that serve as evidence, and in the absence of which the dispute does not have the material means for resolution by testing" (Boltanski, Thévenot 2006: 131). Objects are therefore essential for the construction of stability of worth within the orders. They may also be used for testing if it is needed (Boltanski, Thévenot 2006: 17).

Tests are defined in "On Justification" as "procedures that are capable of reducing the uncertainty of a situation through the achievement of agreement as to the qualification of the beings involved. In this sense, a test encompasses both an evaluation according to a moral standard and an assessment according to the standard of truth" (Boltanski, Thévenot 2006: 360). Tests occur in situations which for different reasons require a clarification of the worth of the actors but also a new definition of the situation itself. Boltanski and Thévenot endeavour to show that in real situations practice of critique consists not in taking some external position but in changing one form of worth (and polity) for another.

The authors claimed that the model presented in "On Justification", despite seemingly presenting a universal model of social practices and proposing general sociology of critique, was limited to begin with (Basaure 2011: 362; see also critique of Honneth 2010). Indeed, the later works of Boltanski and Thévenot, including research, individual or co-authored with others, seem to confirm that this strand of moral sociology and economy of worth is a broader and variegated enterprise. Approaches later proposed separately by Boltanski and Thévenot could be useful for analysis of architecture. They both pay special attention to the role of objects in social situations (inheritance from Latour). But for the spatial theory of ideology, or problematic of ideological space Boltanski's theories might prove more productive. In "Love and Justice as Competences" (2012) he developed a model of regimes of action, which greatly transcend the conflictual model described in "On Justification". Apart from two regimes based on conflict (justification and violence) Boltanski identifies two regimes of peace: love (as agape) and one related to objects (Wagner 1999: 349). The latter is important inasmuch as it can be related to space and its stabilizing functions for social relations. Boltanski observes that "things tell people what to do (...); they keep people in place and propose constraints that play the role of tacit conventions capable of harmonizing people's relationships and their movements." (2012: 70). The regime of objects depicted in such manner is indeed very close to Bourdieu's and Lefebvre's remarks. 
The notion of tests re-emerges in "The New Spirit of Capitalism" (2005) which Boltanski co-authored with Eve Chiapello. The book characterizes the emergence and dissemination in contemporary capitalism of another polity, one based on the idea of a project. All the tests in the projectual polity are tests of strength. They are understood in this context as relating to the continuum local - global (in the systemic sense) and legitimization: "There is a sort of continuum which reaches from the unspecified tests of strength, in which you do not know which forces are at work, to the specified tests of strength, in which only one sort of force is used for the test so that it can be regarded as legitimate" (Basaure 2011: 374). In case of tests of strength the crucial thing is a degree of formalization, or legitimization (Boltanski, Chiapello 2005: 32). The new spirit of capitalism is described as an ideology of a sort (Boltanski, Chiapello 2005: xx-xxi).

Chiapello (2003), after Ricoeur (1986) proposes the understanding of ideology which combines culturalist and Marxist approaches. She locates the distortion effects of ideology as resulting from the surplus of integrative function: "it is because ideology in its group integration function tends to legitimize a social order in its current state (trying to ensure the preservation and reproduction thereof) that it is a theatre of distortion" (Chiapello 2003: 160). This makes room for ideological critique, and one undertaken not from an external position, but by the actors involved: "we therefore have a conception of ideology that can state distortion at any moment in time, since it is impossible to organise tests that are completely fair" (Chiapello 2003: 168). It is also worth remembering that Boltanski (2011) noticed the functioning of ideology in his critical analysis of critical sociology. He observed however, that ideology is effective mostly in the best interests of the dominating classes for it allows the imposition of self-discipline on their members and therefore enabling them to maintain their privileged position. The case is different for the dominated classes, as for them what is crucial is the "relationship between the condition of the systems that ensure running of reality - which can be more or less robust - and the condition of the collective systems actors can rely on to extricate themselves from the reality, challenge its validity and, above all, reduce its powers" (Boltanski 2011: 41). It is virtually in line with the Marxist hope, probably long gone, of the working class as being capable of critique, revolt and revolution. More importantly, it provides arguments for the possibility of utilizing concrete and local struggles and critiques, while preserving the general perspective of ideological space as the context of conflict.
In his characterization of "sociology of emancipation" Boltanski (2011) specifies three kinds of tests, two of which have critical potential. In principle, tests relate to a reality which engages social actors. This reality is not only discoursive but also material and entails objects used in or determining a situation.

Truth tests are a form of tests which are not critical but reassuring. They are undertaken in order to provide "consistency and saturation, a certain pre-established state of the relationship between symbolic forms and states of affairs, in such a way as to constantly reconfirm it" (Boltanski 2011: 103). Their principle is repetition, the task of which is to show a norm and thus they often employ tautologies (Boltanski 2011: 104). In general, the aim of truth tests is to maintain reality as it is, which in turn renders it acceptable or even loved (Boltanski 2011: 105). It is somehow analogous to amor fati, described by Bourdieu in "Distinction" (1984). "The truth test unmasks a universe of signs by exhibiting it in its plenitude and consistency. It makes it manifest and gives lustre to what, in it, stands behind the feeling of respect it inspires." (Boltanski 2011: 113). Interestingly, Boltanski observes that even though truth tests are uncritical, they can be unsuccessful, especially in the case of resistance from non-human actors (objects, machines or animals). Hence even truth tests entail an element of uncertainty with regard to the state of reality and the possibility of its sustenance and reproduction.

Reality tests occur mostly in situations of dispute and have the potential of becoming violence. They enable testing of assertions about reality by confronting them with their actual capabilities (Boltanski 2011: 106). Reality tests rest on the difference between what is and what should be. Uncertainty of the real capabilities of people and things and their mutual relations is a very important element. These tests can either confirm the state of things or transform into critique. They employ recognition and proofs and lean towards compromise in order to validate realness of reality. "In and through acts, the reality test unmasks the powers concealed in the interiority of beings, so that the treatment accorded them is brought into harmony with what they really are and, in this way, the consistency and cohesion of a reality that most closely resembles the representations deployed by truth test is maintained - that is to say, a reality whose correctness is as one with justice" (Boltanski 2011: 113).

Existential tests are most useful for the critique of ideology in architecture and space. Contrary to the two previous types of tests, existential tests have noninstitutional character and maintain individual, local and "lived" traits (Boltanski 2011: 107). They point towards 
previously unrecognized and unidentified factors and facts and therefore often relate to individual experiences, chiefly suffering. Existential tests are radical exactly because they are of a particular and often isolated nature. This peripheral position enables them to question reality (Boltanski 2011: 108). To be politically and critically efficient existential tests demand generalization. "(E)xistential test, at least when it ends up being formulated and made public, (...) unmasks the incompletness of reality and its contingency, by drawing examples from the flux of life that make its bases unstable and challenge it, in such ways as to confront it with the inexhaustible, and hence impossible to totalize, reserve represented by the world" (Boltanski 2011: 113). Such characterization of existential tests brings them close to what Lefebvre wrote about practices of everyday life of lived space as well as to his postulates for difference understood as providing a revolutionary potential (Kipfer 2008: 203).

\section{Architecture as a test}

Sociology of critique and Boltanski's sociology of emancipation are not directly concerned with space or architecture. Nevertheless, I will argue that certain elements of these theories can be utilized for critical analysis. It is especially so as special attention is paid to objects as active elements in situations and tests. Furthermore, Boltanski himself tries to combine his own sociology of critique with critical sociology (of which Bourdieu is the main representative) and therefore to reformulate pragmatic sociology by including normative aspects. It seems that similar reformulation is also needed in contemporary critical urban studies, which on the one hand concentrate on the outwardly overwhelming power of neo-liberalism and on the other has difficulty in generalizing local problems like gentrification or privatization of commons and mobilizing protests. Ideological critique should not be used to condemn enemies but rather to facilitate construction of practical and institutional solutions and make them available to social actors in their everyday problems (see: Celikates 2006: 36). Critique of space and architecture is in this context vital because of its object which is of a practical, everyday, material and common nature.

To characterize architecture as a test is not to simply use sociological categories for the analysis of materiality or the depiction of the building process. The notion of a test enables consideration of architecture as functional and instrumental for the confirmation or negation of existing lived reality on the one hand, and attribution of the critical role of architecture on the other.
Why then can architecture be considered a test? Firstly, architecture, understood as a process of construction and building of material structures, has a direct influence on society. Secondly, socio-spatial systems are inherently unstable and therefore can be characterized, after Lefebvre (2010), as processes of the social production of space. These suppositions are related to the issue of ideological space, outlined above. Considering three kinds of tests, we can see that architecture is, in a covert or overt way, similarly burdened with providing solutions to social problems. In principle, architecture provides material and practical answers to the questions about reality. Alike tests, it basically settles arguments about accepted actions or practices and organizes lifeworlds. Architectural solutions are always provisional and elaborated with unequal share from various social actors and institutions, which leaves open the possibility of critique. Moreover, its aim can be either reproduction or innovation of existing reality and social relations. The unequal status of the social actors involved in architecture is especially striking in most cases when participation in the process of construction is restricted and excludes everyone except experts, for instance during architectural competitions or in professional associations. It serves the purpose of making the architectural test purer by the elimination of criteria not directly related to architectural discourse and practice. At the same time, it disables critique of a different sort, which would be able to reveal and include aspects such as social costs and responsibilities, and use a particular building for ideological critique.

Architecture as a truth test which confirms existing reality is probably most common. It is so because of the dominated situation of architecture as a profession, in spite of its ostensible autonomy (Jones 2009). Confirmation of reality by architecture is evident for instance in repetition of similar material structures in different geographical, historical and social circumstances. It works to some extent as a simple and planned misperception of architecture as a representation of society in material forms. However, it must be noted that especially in this case the context is crucial. For instance, a housing estate of tower blocks can be considered a truth test in modern Europe, but not necessarily in contemporary cities in Asia (see: Yuen, Yeh 2011) or in European cities in the 1940s when they oftentimes were one of the means of social change (see: Hall 2002). Similarly, suburbia - the epitome of architectural repetition - can be either strengthening existing social relations or constitute major changes in city functions in a wider context (King 2004: 97-110) and is perceived by people as utopian (see: Fishman 1987). 
Anyhow, the main aim of architecture as a truth test is as best as possible reproduction of socio-spatial systems and relations of power by means appropriate to the existing context.

Reality tests as potentially reformative situations can be identified in architecture which serves to correct or amend the system. Thus it is usually both innovative (especially in formal aspects), conservative and confirmative. In other words, it takes into consideration the resolution of controversial or debatable issues or even crises in a way which tends toward preservation of existing socio-spatial arrangements. Iconic buildings, as characterized by Sklair (2010) can serve as an example of an architectural reality test. It is also noticeable in the postmodern architecture in late $20^{\text {th }}$ century Poland, where postmodernism was not a comprehensive paradigm, but rather an answer to the state-controlled urban design programmes. New postmodern buildings were projected and erected in a manner which can be called a correction of the aesthetic and architectural system, but without enough power to overcome problems of central planning (see: Klein 2013; Gzowska, Klein 2013).

Architecture as an existential test is perhaps the most complicated case, mainly because it brings forward the issue of (im)possibility of comprehensive critique. The other reason might be that architecture is considered to be for architects (i. e. experts), which hinders its wider social functions. Certain trends in Modernist architecture, as described by Frampton (2004: 248-279) included strong postulates of social change. Leach, after Jameson (2008), arguments that Modernism disappointed hopes for wide-ranging change because it was not able to separate an aesthetic revolution from a social one (1999: 115). Jameson himself noted that "the symbolic act of high modernism, which seeks to resolve contradiction by stylistic fiat (even though its resolution may remain merely symbolic), is of a very different order and quality from that of postmodernism that simply ratifies the contradictions and fragmented chaos all around it by way of an intensified perception of, a mesmerized and well-nigh hallucinogenic fascination with, those very contradictions themselves" (2008: 369). Significantly, we now have to do with an architectural trend which Hatherley calls pseudomodernism. He shows that pseudomodernism shares with postmodernism its complete submission to market relations, being at the same aesthetically Modernist (2010: xx). Nevertheless, Leach argues that architecture can be an instrument of social revolution since it is more bound with society than other forms of aesthetic expression (Leach 1999: 115).

It is also worth noting that an architectural test can be undertaken at different scales and can refer equally well to whole buildings or larger urban plans as well as to particular apartments, public spaces or typically utilitarian structures such as bridges, roads, etc. In other words, ideological and social tests can function with regard to various spaces, even when different forms of social life need to be preserved.

\section{Conclusion: testing architecture}

The influence of architecture on society is undertheorized. Moreover, architectural and urban plans, although ostensibly innovative, are actually subordinated to the game rules of the market which render them instrumental in the reproduction of the social relations of domination. Nonetheless, overlooking the social aspects of architecture and space in general, and especially their critical potential, is not going to help. The postulate of social responsibilities and roles of architecture do not come from desperation, but from a simple fact that without spatial changes social change is inconceivable. "Space assumes regulatory role when and to the extent that contradictions - including the contradictions of space itself - are resolved" (Lefebvre 2010: 420). The role of architecture is equally to enable conflicts and struggles and to propose their solutions. Furthermore, architecture as much as possible should have a character of an existential test, which would enable connections between general level and local struggles. "The transformation of society presupposes a collective ownership and management of space founded on the permanent participation of the 'interested parties', with their multiple, varied and even contradictory interests. It thus also presupposes confrontation (...)" (Lefebvre 2010: 422).

Such tasks are already present but insufficiently appreciated in architectural practice. The main thing is to accept fundamental uncertainty and the contingency of space as well as formal and, above all, the social responsibility of architecture. Only then is it possible to multiply architectural existential tests regarding prevalent relations of domination. In other words, the postulate here is to acknowledge vital openness of space and its critical social importance. While today it is an arduous task to even imagine alternatives for market capitalism, it is still more important not to ignore little struggles and resistances. These instances are always stronger when they regard space or have spatial existence. Hence the role of the architect is to design structures capable of generalization of emancipatory practices. This role is strengthened because of the practical competences and technical skills which architects and planners undoubtedly possess, under the condition of accepting dependent role of architecture (Till 2009). 
It is also worth noting that every uncertainty, conflict and test in space can to various degrees be critically utilized. For instance, as numerous examples of public art testify, it is easier to conduct an existential test in public space than in one's private or intimate space, although it is achievable.

Perhaps contrary to widespread approaches, architectural practice is not about designing innovative structures while overawed by technology, size or height. In fact, it would be in accordance with mid-twentieth century urban capitalism, and as Goonewardena points out, "the central lesson of the 20 century for planning [and architecture] cannot be forgotten: not to trust either the 'market' or the 'expert' (2003: 215). On the contrary, the aim is to include architecture into the realm of social critique of material ideologies. It is effectively what Jameson postulated a few decades ago: "The essential would (...) be that they [architects] are able to form conceptions and Utopian images of such projects, against which to develop a self-consciousness of their concrete activities in this society" (2008: 361). As I tried to argue, those conceptions and utopias do not necessarily have to grow from some external position or fully alternative visions as they rarely are grounded in experience and their introduction is all the more problematic. Rather, possible critiques are already here, within - or between - relations of dominations in their material and concrete manifestations. "This concrete existence of radically different spaces elsewhere (...) is what objectively opens the possibility for the coming into being and development of 'counterhegemonic values' here" (Jameson 2008: 361).

To return to social critique as envisioned by Boltanski, it is worth recalling his remarks which can easily be adapted to critical strategies of space: "critique cannot be determined solely by its opposition to the established order of reality, considered in its opaque generality, but also, or above all, by its reference to possibilities, already identifiable in the experience of the world, of which suffering and desire are the manifestations in the flux of life" (2011: 113). What is important, critique of space is not just negative. On the contrary, it allows practical and material shaping of the ideologies of change by way of unceasing tests. Similarly, it is not only the indignant moaning against the all-pervading neo-liberalism which is easily neutralised or naturalised. Rather, it is the strengthening of critical practice, which is anyway inevitable because of the ideological mediation of limited space. It is not about transcendence, because critical practice is already there - within and between the material ideologies of space.

\section{References}

Althusser, L. 1994. Ideology and ideological state apparatuses (notes towards an investigation), in S. Žižek (Ed.). Mapping ideology. London, New York: Verso, 100-140.

Basaure, M. 2011. An interview with Luc Boltanski: criticism and the expansion of knowledge, European Journal of Social Theory 14(3): 361-381.

http://dx.doi.org/10.1177/1368431011412350

Bénatouill, T. 1999. A tale of two sociologies: the critical and the pragmatic stance in contemporary French sociology, European Journal of Social Theory 2(3): 379-396. http://dx.doi.org/10.1177/136843199002003011

Blokker, P.; Brighenti, A. 2011. An interview with Laurent Thévenot: on engagement, critique, commonality and power, European Journal of Social Theory 14(3): 383-400. http://dx.doi.org/10.1177/1368431011412351

Boltanski, L. 2011. On critique. A sociology of emancipation. Translated by G. Elliott. Cambridge, Malden: Polity Press.

Boltanski, L. 2012. Love and justice as competences. Translated by C. Porter. Cambridge, Malden: Polity Press.

Boltanski, L. Chiapello, E. 2005. The new spirit of capitalism. Translated by G. Elliott. London, New York: Verso.

Boltanski, L. Thévenot, L. 2006. On justification. economies of worth. Translated by C. Porter. Princeton, Oxford: Princeton University Press.

Bourdieu, P. 1984. Distinction. A social critique of the judgment of taste. Translated by R. Nice. Cambridge: Harvard University Press.

Bourdieu, P. 1990. The logic of practice. Translated by R. Nice. Stanford: Stanford University Press.

Bourdieu, P. 1995. Outline of a theory of practice. Translated by R. Nice. Cambridge, New York, Melbourne: Cambridge University Press.

Bourdieu, P. 1999. Scattered remarks, European Journal of Social Theory 2(3): 334-340. http://dx.doi.org/10.1177/13684319922224563

Bourdieu, P. 2005. The social structures of the economy. Translated by C. Turner. Cambridge, Malden: Polity Press.

Bourdieu, P.; Eagleton, T. 1994. Doxa and common life: an interview, in S. Žižek (Ed.). Mapping ideology. London, New York: Verso, 265-277.

Bourdieu, P., et al. 1999. The weight of the world. social suffering in contemporary society. Translated by P. P. Ferguson, S. Emanuel, J. Johnson, S. T. Waryn. Stanford: Stanford University Press.

Castells, M. 1977. The urban question. London: Edward Arnold.

Celikates, R. 2006. From critical social theory to a social theory of critique: on the critique of ideology after the pragmatic turn, Constellations 13(1): 21-40. http://dx.doi.org/10.1111/j.1351-0487.2006.00438.x

Chiapello, E. 2003. Reconciling the two principal meanings of the notion of ideology. The example of the concept of the 'Spirit of Capitalism', European Journal of Social Theory 6(2): 155-171. http://dx.doi.org/10.1177/1368431003006002001

Cuthbert, A. R. 2006. The form of cities. Political economy and urban design. Malden, Oxford, Carlton: Blackwell Publishing.

Eagleton, T. 1991. Ideology. an introduction. London, New York: Verso. 
Fishman, R. 1987. Bourgeois utopias. The rise and fall of suburbia. New York: Basic Books Publishers.

Frampton, K. 2004. Modern architecture. A critical history. London, New York: Thames \& Hudson.

Goonewardena, K. 2003. The future of planning at the "end of history", Planning Theory 2(3): 183-224. http://dx.doi.org/10.1177/147309520323004

Goonewardena, K. 2004. Urban space and political consciousness: a report on theory, Review of Radical Political Economics 2004(spring): 155-176. http://dx.doi.org/10.1177/0486613404264039

Gzowska, A.; Klein, L. (Eds.). 2013. Postmodernizm polski. Architektura i urbanistyka. P2. [Polish postmodernism. Architecture and urban planning P2]. Warszawa: 40000 malarzy.

Hall, P. 2002. Cities of tomorrow. An intellectual history of urban planning and design in the twentieth century. 3rd ed. Malden, Oxford, Carlton: Blackwell Publishing.

Harvey, D. 1987. Flexible accumulation through urbanization, Antipode 19(3): 260-286. http://dx.doi.org/10.1111/j.1467-8330.1987.tb00375.x

Hatherley, O. 2010. A guide to the new ruins of Great Britain. London, New York: Verso.

Honneth, A. 2010. Dissolutions of the social: on the social theory of Luc Boltanski and Laurent Thévenot, Contellations 17(3): 376-389. http://dx.doi.org/10.1111/j.1467-8675.2010.00606.x

Jameson, F. 2008. Architecture and the critique of ideology, in F. Jameson. The ideologies of theory. London, New York: Verso.

Joas, H.; Knöbl, W. 2011. Between structuralism and theory of practice: the cultural sociology of Pierre Bourdieu, in S. Susen, B. S. Turner (Eds.). The legacy of Pierre Bourdieu. Critical essays. London, New York, Delhi: Anthem Press, $1-32$.

Jones, P. 2009. Putting architecture in its social place: a cultural political economy of architecture, Urban Studies 46(12): 2519-2536. http://dx.doi.org/10.1177/0042098009344230

King, A. D. 2004. Spaces of global cultures. architecture urbanism identity. London: Routledge.

Kipfer, S. 2008. How Lefebvre urbanized Gramsci. hegemony, everyday life and difference, in K. Goonewardena, S. Kipfer, R. Milgrom, C. Schmid (Eds.). Space, difference, everyday life. Reading Henri Lefebvre. New York, London: Routledge, 193-211.

Kipfer, S.; Goonewardena, K.; Schmid, M.; Milgrom, R. 2008. On the production of Henri Lefebvre, in K. Goonewardena, S. Kipfer, R. Milgrom, C. Schmid (Eds.). Space, difference, everyday life. Reading Henri Lefebvre. New York, London: Routledge, 1-23.

Klein, L. (Ed.). 2013. Postmodernizm polski. Architektura i urbanistyka $P 1$ [Polish postmodernism. architecture and urban planning P1]. Warszawa: 40000malarzy.

Latour, B. 1993. Pasteurization of France. Translated by A. Sheridan, J. Law. Cambridge, London: Harvard University Press.

Leach, N. 1999. Architecture or revolution?, in N. Leach (Ed.). Architecture and revolution. Contemporary perspectives on Central and Eastern Europe. London, New York: Routledge, 112-126.
Lefebvre, H. 2000. Writings on cities. Translated by E. Kofman, E. Lebas. Oxford, Malden: Blackwell.

Lefebvre, H. 2003. The urban revolution. Translated by R. Bononno. Minneapolis, London: University of Minnesota Press.

Lefebvre, H. 2010. The production of space. Translated by D. Nicholson-Smith. Malden, Oxford, Victoria: Blackwell.

Massey, D. 2005. For space. Los Angeles, London, New Delhi, Singapore, Washington DC: SAGE.

Ricoeur, P. 1986. Lectures on ideology and utopia. Translated by G. H. Taylor. New York, Guildford: Columbia University Press.

Savage, M. 2011. The lost urban sociology of Pierre Bourdieu, in G. Bridge, S. Watson (Eds.). The new Blackwell companion to the city. Malden, Oxford: Blackwell, 511-520.

Sklair, L. 2010. Iconic architecture and the culture-ideology of consumerism, Theory, Culture \& Society 27(5): 135-159. http://dx.doi.org/10.1177/0263276410374634

Stanek, Ł. 2011. Henri Lefebvre on space. Architecture, urban research, and the production of theory. Minneapolis: University of Minnesota Press.

Swartz, D. L. 2005. From critical sociology to public intellectual: Pierre Bourdieu and elaboration. New York, Boston, Dordrecht, London, Moscow: Kluwer Academic Publishers, 333-364.

Tafuri, M. 1998. Toward a critique of architectural ideology, in K. M. Hays (Ed.). Architecture theory since 1968. Cambridge MA, London: MIT Press, 2-35.

Thévenot, L. 2011. Power and oppression from the perspective of engagements: a comparison with Bourdieu's and Dewey's critical approaches to practical activities, Irish Journal of Sociology 19(1): 35-67. http://dx.doi.org/10.7227/IJS.19.1.3

Till, J. 2009. Architecture depends. Cambridge MA, London: MIT Press.

Wagner, P. 1999. After justification: repertoires of evaluation and the sociology of modernity, European Journal of Social Theory 2(3): 341-357. http://dx.doi.org/10.1177/13684319922224572

Yuen, B.; Yeh, A. G. O. (Eds.). 2011. High-rise living in Asian cities. Dordrecht, Heidelberg, London, New York: Springer. http://dx.doi.org/10.1007/978-90-481-9738-5

Žižek, S. 1994. The spectre of ideology, in S. Žižek (Ed.). Mapping ideology. London, New York: Verso, 1-33.

\section{KAROL KURNICKI}

Institute of Sociology, Jagiellonian University, Grodzka 52, 31-044 Kraków, Poland.E-mail: karol.kurnicki@uj.edu.pl

Karol Kurnicki is a $\mathrm{PhD}$ candidate in the Institute of Sociology of Jagiellonian University in Kraków, Poland. His main areas of interests are urban sociology, urban studies, critical sociology and applied social sciences. In his doctoral dissertation "Ideologies in a city. On the social production of urban space." he analyses contemporary urban ideas and ideologies and their influence on local policies, economies and social practice. 